Izvorni znanstveni rad - UDK - 616.89-008.454

159.972 .072

\title{
Doprinos ruminacije, usredotočenosti, potiskivanja misli i metakognitivnih vjerovanja objašnjenju depresivnosti
}

\author{
Katija Kalebić Jakupčević \\ Obrt za savjetovanje MOPIS, Split, Hrvatska \\ Ivanka Živčić-Bećirević \\ Odsjek za psihologiju, Filozofski fakultet Sveučilišta u Rijeci, Hrvatska
}

\begin{abstract}
Sažetak
Dosadašnje su studije o ulozi kognitivnih procesa u objašnjenju nastanka i razvoja depresije upućivale na važnost stjecanja jasnijeg uvida u njihove međusobne odnose, stoga se ovim istraživanjem pokušalo provjeriti kakav je doprinos metakognitivnih vjerovanja, ruminacije, potiskivanja misli i usredotočenosti objašnjenju razine depresivnosti te ispitati kakva je njihova međusobna povezanost kod kliničke i ne-kliničke skupine. Kliničku skupinu $(N=70)$ su sačinjavale osobe oboljele od depresivnog poremećaja, a ne-kliničku $(N=70)$ osobe bez poteškoća mentalnog zdravlja. Dobiveni su rezultati pokazali da depresivne osobe više ruminiraju, imaju pozitivnija vjerovanja o ruminaciji, nižu usredotočenu svjesnost, češće potiskuju misli te imaju negativnija vjerovanja o opasnosti i posljedicama ruminacije nego mentalno zdrave osobe. Doprinos je ruminacije kod depresivnih osoba posredovan negativnim vjerovanjima o posljedicama ruminacije dok je kod mentalno zdravih osoba ruminacija direktno povezana sa stupnjem depresivnosti. Rezultati daju dodatne smjernice u psihoterapijskom pristupu koji bi u tretmanu depresivnog poremećaja trebao uključivati i tretman ruminacije i trening usredotočene svjesnosti.
\end{abstract}

Ključne riječi: depresivnost, ruminacija, metakognitivna vjerovanja, usredotočena svjesnost, potiskivanje misli

\section{Uvod}

Depresija je psihijatrijska bolest $\mathrm{s}$ tisuću lica, biopsihosocijalni poremećaj raspoloženja koji se očituje pojavom niza kognitivnih, ponašajnih i afektivnih simptoma. Istraživanja Svjetske zdravstvene organizacije (WHO, 2012) upućuju na trend sve većeg porasta učestalosti depresivnog poremećaja te se očekuje da bi do 2030. godine depresija mogla predstavljati vodeću dijagnozu u svijetu. Upravo zbog

Katija Kalebić Jakupčević, Šime Ljubića 19, 21000 Split, Hrvatska. E-pošta: katijakalebic@net.hr 
navedenog, proteklih su se desetljeća mnoga istraživanja bavila proučavanjem misaonih procesa i načina razmišljanja vezanih uz depresivnu simptomatologiju. Pokazalo se da su simptomi koje nalazimo kod depresivnih osoba najčešće i najznačajnije povezani s načinom razmišljanja koji se naziva ruminacija.

U najranijim je istraživanjima (Martin i Tesser, 1989) ruminacija bila definirana kao skup svjesnih misli o nekoj temi te kao usmjerenost prema ostvarenju ciljeva ili prema neskladu između željenih ciljeva i trenutnih postignuća. No, novije spoznaje ruminaciju definiraju kao proces perseverativnog mišljenja o vlastitim emocijama i problemima, bez naglaska na specifičnost sadržaja misli (Smith i Alloy, 2009). Premda osobe često vjeruju da je ruminacija usmjerena rješavanju njihovih problema, ona zapravo ometa takvo ponašanje i potiče kontinuirano izlaganje stresnim podražajima čime doprinosi održavanju ruminativnog načina razmišljanja (Lybomirsky, Tucker, Caldwell i Berg, 1999).

Za razumijevanje nastanka i održavanja ruminacije kao strategije suočavanja važno je spomenuti nekoliko modela. Jedan je od najranijih proizašao iz Teorije vrste odgovora (Nolen-Hoeksema, 1991) koja navodi da će osobe ruminiranjem uslijed depresivnog raspoloženja pojačati i produžiti trajanje takvog raspoloženja te povećati trajanje depresivne epizode. Smatra se da je tendencija ruminacije stabilna te da predstavlja moderatorsku varijablu individualnih razlika. $U$ analizi njihove teorije Brotman i Derubies (2004) navode da ruminacija u kontekstu depresivnog raspoloženja pojačava i prolongira depresivne simptome te na taj način vodi depresivnom poremećaju. Ruminacija aktivira negativne misli i sjećanja, čini neefikasnim rješavanje problema, ometa ponašanje usmjereno na problem, vodi socijalnoj izolaciji te porastu depresivnih simptoma. Osnovni su nedostaci ove teorije nedovoljna objašnjenja individualnih razlika u tendenciji ruminacije te nejasna priroda odnosa između tendencije ruminacije $\mathrm{i}$ iskustva depresivnosti.

U svrhu dodatnih pojašnjenja ovih odnosa Wells i Mathews (1996) su predložili svoj S-REF model (engl. Self-Regulatory Executive Function Model), odnosno model samoregulirajućih izvršnih funkcija. U model su uključili kognitivne i metakognitivne faktore koji mogu utjecati na kontrolu i održavanje emocionalnih poremećaja. Utvrdili su da se upotrebom neefikasnih strategija suočavanja u stresnim situacijama povećava doživljaj stresa i vjerojatnost nastanka emocionalnih poteškoća. Ruminacija se kao jedna takva strategija suočavanja pokazala važnim prediktorom pojavnosti depresivnog poremećaja. Ruminacija je u interakciji s negativnim kognitivnim stilovima čime sudjeluje u održavanju samog poremećaja. Moulds, Yap, Kerr, Williams i Kandris (2010) su utvrdili da osobe s visokim pozitivnim vjerovanjem o ruminaciji više ruminiraju nakon doživljenoga negativnog iskustva te da osobe koje vjeruju da im ruminacija koristi više ruminiraju od osoba s niskim pozitivnim vjerovanjem bez obzira je li ishod bio pozitivno ili negativno iskustvo.

Uzevši u obzir postavke S-REF modela, Papageorgiou i Wells (2001a) su u svom istraživanju krenuli od pretpostavke da je kod osoba s emocionalnim 
poteškoćama razina znanja i vjerovanja povezana s ruminiranjem. Naime, njihova pretpostavka jest da je perseverativno negativno razmišljanje povezano $\mathrm{s}$ metakognitivnim vjerovanjima o korisnosti i o posljedicama takva razmišljanja. U preliminarnoj su studiji utvrdili da su svi oboljeli imali pozitivna i negativna vjerovanja o ruminaciji. Sadržaj pozitivnih metakognitivnih vjerovanja odnosio se na ruminaciju kao strategiju suočavanja dok su se negativna metakognitivna vjerovanja o ruminaciji odnosila na nekontrolabilnost i moguću štetu zbog ruminacije te na interpersonalne i socijalne posljedice ruminacije. Na temelju svojih nalaza autori su sastavili instrumente za mjerenje pozitivnih i negativnih metakognitivnih vjerovanja o ruminaciji. Empirijski dokazi provedenih studija (Papageorgiou i Wells, 2001a, 2003) pokazuju da su pozitivna metakognitivna vjerovanja o ruminaciji značajno i pozitivno povezana s ruminacijom i depresijom kod kliničkog i ne-kliničkog uzorka te da su oba negativna metakognitivna vjerovanja o ruminaciji značajno i pozitivno povezana s ruminacijom i depresijom kod kliničkog i ne-kliničkog uzorka ispitanika. Studije su pokazale da pozitivna metakognitivna vjerovanja o ruminaciji kao strategiji suočavanja vode ruminaciji kao načinu suočavanja sa stresom. Međutim, negativne posljedice ovakvog načina procesiranja vode negativnim procjenama kontrolabilnosti i posljedicama ruminacije koje jednim dijelom posreduju u povezanosti ruminacije i depresije (Papageorgiou i Wells, 2001a, 2003; Roelofs, Huibers, Peeters, Arntz i van Os, 2010).

Na temelju su rezultata svojih istraživanja Papageorgiou i Wells (2001a, 2001b) predložili klinički model ruminacije i depresije prema kojem pozitivna vjerovanja o koristi i prednostima ruminacije utječu na motivaciju osobe da ruminira dok su negativna metakognitivna vjerovanja značajno povezana $\mathrm{s}$ ruminacijom i sa stupnjem depresivnosti kod depresivnih osoba, pri čemu negativne procjene ili vjerovanja jednim dijelom mogu biti medijator odnosa između ruminacije $\mathrm{i}$ depresivnosti. U svojoj su drugoj studiji na ne-kliničkom studentskom uzorku dobili nešto drugačije rezultate $i$ to prvenstveno o povezanosti ruminacije, negativnih vjerovanja i depresivnosti (Papageorgiou i Wells, 2003). Naime, na ne-kliničkom uzorku je utvrđena direktna povezanost ruminacije i depresivnosti.

Uz značajan doprinos ruminacije objašnjenju depresivnog poremećaja u istraživanjima se posljednjih godina istaknuo i pojam usredotočene svjesnosti (engl. Mindfulness, Williams, 2008). Usredotočena svjesnost predstavlja specifičan način usmjeravanja pažnje (Borders, Earleywine i Jajodia, 2010; Shapiro, Carlson, Astion i Freedman, 2006), odnosno uključuje usmjeravanje pažnje na trenutne, a ne na prošle ili buduće događaje. Osobe koje su više usredotočene imaju veću sposobnost svjesnog preusmjeravanja pažnje s neugodnih sjećanja iz prošlosti ili s pretjeranih briga o budućim događajima, u odnosu na osobe koje imaju nižu usredotočenu svjesnost (Bishop i sur., 2004). Dosadašnja su istraživanja uputila na negativnu povezanost ruminacije i usredotočene svjesnosti (Borders i sur., 2010; Brown i Ryan, 2003; Coffey i Hartman, 2008) sugerirajući pri tome medijacijsku ulogu ruminacije u odnosu usredotočenosti te depresivnih i anksioznih simptoma. Veća je razina 
usredotočene svjesnosti povezana s manjom impulzivnosti i s većom svjesnosti pri odabiru reakcija i načina ponašanja koja su u skladu s potrebama i vrijednostima pojedinca (Brown i Ryan, 2003). Neki autori (Bishop i sur., 2004; Chambers, Lo i Allen, 2008) sugeriraju da je usredotočena svjesnost jedan oblik mentalnog treninga koji potiče sposobnost samoregulacije pažnje i povećava kognitivnu fleksibilnost te unapređuje izvršne funkcije čime djeluje na smanjenje tendencije impulzivnom i agresivnom ponašanju.

Depresivne osobe često navode da su njihove negativne misli uzrok njihova zadovoljstva te da se s njima suočavaju pokušavajući ne misliti na njih (Wegner i Zanakos, 1994). Kada osoba potiskuje određene misli, to postiže misleći o nečem drugom, što onda indirektno postaje povezano s tim mislima. Kontinuirano potiskivanje misli na taj način čini te misli stalno prisutnima (Purdon, 1999; Spinhoven i van der Does, 1999). U odnosu na osobe koje nikada nisu imale depresivnu epizodu depresivne osobe imaju značajno višu razinu kroničnog potiskivanja misli te ulažu mnogo više truda u pokušaju regulacije emocija kako bi postigli i zadržali pozitivno mentalno stanje (Wenzlaff i Rude, 2002). Premda bi nastojanjem da zadrže mentalnu kontrolu trebali kontrolirati i neželjene misli, često se događa upravo suprotno i negativne misli postaju učestalije (Beevers, Wenzlaff, Hayes i Scott, 1999). Objašnjenje se ove pojave nalazi u teoriji ironičnih procesa (Wegner, 1994), koja sugerira da potiskivanje misli uključuje dva mehanizma: namjerni proces distrakcije, kojim se odvraća pažnja od neželjenih misli i promatrajući mehanizam, kojim se opažaju neželjene misli koje zahtjevaju distrakciju. Premda je proces distrakcije svjestan i često učinkovit, promatrajući je sistem često nesvjestan i ne zahtjeva mnogo mentalnog napora. $S$ jedne strane, ova dva procesa pomažu zadržavanju neželjenih misli izvan razine svjesnosti, no s druge strane, promatrajućim se sistemom održava usmjerenost na te neželjene misli, koje u uvjetima kada je distrakcija onemogućena, postaju problematične. U tim su uvjetima osobe mnogo češće i više svjesne neželjenih misli nego što bi bile da nisu ni pokušale potiskivati svoje misli. Povezanost potiskivanja misli i depresivnosti upućuje na to da i samo nastojanje depresivne osobe da zaustavi negativno emocionalno stanje može biti povezano s porastom stupnja depresivnosti. Interakcija kroničnog potiskivanja misli i podložnosti za pojavu depresije (kod osoba koje su posebno sklone negativnim mislima) čini takve osobe rizičnijima za depresivni poremećaj (Reynolds i Wells, 1999).

Zaključno se može reći da dosadašnja istraživanja depresivnih ruminacija uglavnom potvrđuju da ruminacija može biti prediktor depresivne simptomatologije, da negativno utječe na strategije rješavanja problema, pažnju, koncentraciju i motivaciju te da kod depresivnih osoba utječe na trajanje depresivnog raspoloženja. Ipak, u tim se istraživanjima navode i nedostaci te preporuke za daljnje studije koje naglašavaju potrebu za uključivanjem različitih uzoraka kako iz kliničke tako i iz nekliničke populacije. Temeljem je dosadašnjih spoznaja i opisanih modela u ovom 
istraživanju pretpostavljen odnos između ruminacije, metakognitivnih vjerovanja, usredotočene svjesnosti, potiskivanja misli i stupnja depresivnosti prikazan na Slici 1.

Slika 1. Pretpostavljeni odnos varijabli

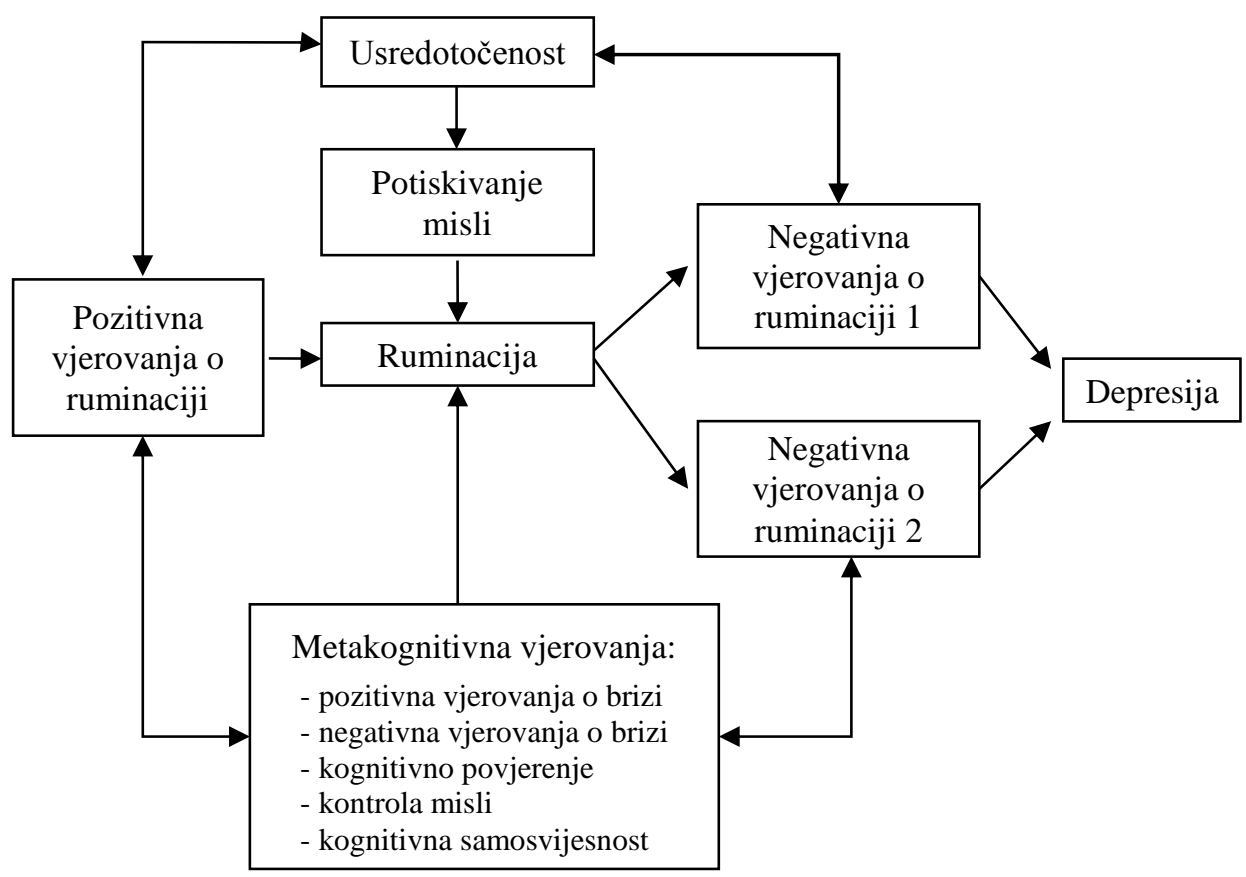

Legenda: Negativna vjerovanja o ruminaciji 1 - negativna vjerovanja o nekontrolabilnosti i štetnosti ruminacije; Negativna vjerovanja o ruminaciji 2 - negativna vjerovanja o interpersonalnim i socijalnim posljedicama ruminacije

Cilj je istraživanja bio utvrditi doprinos metakognitivnih vjerovanja, ruminacije, potiskivanja misli i usredotočenosti objašnjenju razine depresivnosti kod kliničke i ne-kliničke skupine. Postavljene su hipoteze prema kojima se: 1) očekuje se da će pozitivnija vjerovanja o ruminaciji, viši stupanj potiskivanja misli, viša razina usredotočenosti, negativnija vjerovanja o brizi, niže kognitivno povjerenje i niža samosvijest te veća potreba za kontrolom misli biti povezana s višom razinom depresivnosti te da će tom odnosu posredovati viši stupanj ruminacije; 2) obrazac povezanosti navedenih metakognitivnih vjerovanja i misaonih procesa pokazivat će sličan trend kod kliničke i ne-kliničke skupine; 3) navedene dvije skupine će najbolje diskriminirati stupanj ruminacije. 


\section{Metoda}

\section{Sudionici}

U ispitivanju je sudjelovala klinička i ne-klinička skupina sudionika. Kliničku je skupinu činilo 35 osoba muškog i 35 osoba ženskog spola prosječne dobi $M=51.01$ godina. Većina njih je u bračnoj zajednici $(77.14 \%)$, sa završenom srednjom stručnom spremom (57.14\%) i nezaposlena (62.85\%). Uzorak su činili oboljeli od depresivnog poremećaja koji su: hospitalizirani na Klinici za psihijatriju KBC-a Split (35.71\%); u ambulantnom psihijatrijskom tretmanu na Klinici (32.85\%) te u tretmanu Dnevne bolnice Klinike (17.14\%). Ne-kliničku skupinu su sačinjavale osobe bez poteškoća mentalnog zdravlja od kojih 26 muškaraca i 44 žene prosječne dobi $M=48.34$ godine. Njih $74.28 \%$ je u bračnoj zajednici, sa završenom srednjom stručnom spremom (60\%) i nezaposleno (77.14\%). Budući da su skupine ujednačene po: spolu, dobi, bračnom, obrazovnom i socioekonomskom statusu, primjena instrumentarija na ne-kliničkoj skupini vršena je nakon prikupljenih podataka na kliničkoj skupini.

\section{Postupak}

S obzirom na to da su za potrebe ovog istraživanja mjerni instrumenti prevedeni na hrvatski jezik, bilo je potrebno provesti preliminarni dio istraživanja koji je obuhvaćao provjeru njihovih metrijskih karakteristika. U prijevodu su sudjelovali neovisni prevoditelji različitih struka čiji su prijevodi pojedinih skale objedinjeni te su odabrane čestice koje su bile sadržajno najrazumljivije i koje su imale najveće slaganje među prevoditeljima. Prevedene su skale primijenjene na studentskom uzorku koji je činilo 126 sudionika od čega 106 žena i 20 muškaraca, prosječne dobi $M=21.93(S D=3.59)$. Većina ih ima završenu srednju stručnu spremu $(91.26 \%)$, nezaposleni su $(92.06 \%)$ te svoje materijalno stanje procjenjuju prosječnim $(M=3.01$, $S D=0.43$ ). Podatke su prikupljali psiholozi zaposleni na Sveučilištu u Splitu. Podaci su prikupljani grupno, sudjelovanje je u ispitivanju bilo dobrovoljno i anonimno. Predispitivanjem su utvrđene vrlo zadovoljavajuće mjerne karakteristike svih skala te se, nakon zadovoljavajuće dodatne provjere unazadnim prijevodom čestica na engleski jezik i uz suglasnost Etičkog povjerenstva započelo s istraživanjem. Podatke su za kliničku skupinu prikupljali klinički psiholozi Klinike za psihijatriju KBC-a Split. Nakon usmenog pristanka i dogovora s nadležnim specijalistom psihijatrom sudionici su dobili upitnike koje su nakon popunjavanja zalijepili u pripremljene omotnice, koje su nakon toga predane glavnom istraživaču. Podaci za ne-kliničku skupinu prikupljani su metodom "snježne grude" pri čemu su studenti Filozofskog fakulteta u Splitu zatražili usmeni pristanak za sudjelovanje u istraživanju dvoje ljudi različitog spola. U odabiru su ljudi korišteni podaci o kliničkoj skupini te su sudionike odabirali prema dobi, bračnom, obrazovnom i socioekonomskom statusu koji je sličan ili jednak onom dobivenom u kliničkoj skupini. 


\section{Instrumenti}

Upitnik sociodemografskih podataka konstruiran je u svrhu utvrđivanja nekih obilježja sudionika (dob, spol, stručna sprema, bračni, obiteljski i radni status te procjena materijalnog stanja). U sklopu Upitnika koji su popunjavali sudionici iz nekliničke skupine nalazilo se i pitanje "Jeste li se ikada liječili kod specijaliste za mentalno zdravlje (psiholog, psihijatar)?" na temelju kojeg su u daljnje analize uključeni sudionici koji se nikada nisu liječili, odnosno nisu imali poteškoća mentalnog zdravlja.

Upitnik metakognitivnih vjerovanja (Metacognitions Questionnaire 30-MCQ30; Wells i Cartwright-Hatton, 2004) sastoji se od 30 čestica. Stupanj slaganja s pojedinim česticama procjenjuje se od 1 (uopće se na slažem) do 4 (u potpunosti se slažem). Upitnik ima 5 subskala: 1) subskala pozitivnih vjerovanja o brizi odnosi se na pozitivna vjerovanja o korisnosti brige pri rješavanju problema (primjer čestice: "To što se brinem pomaže mi da izbjegnem probleme u budućnosti."); 2) subskala negativnih vjerovanja o nekontrolabilnosti i opasnosti brige odnosi se na vjerovanje da je briga, tj. perseverativno mišljenje nekontrolabilno i opasno (npr. "Mogao bih se razboljeti od brige."); 3) subskala kognitivne kompetentnosti uključuje povjerenje u vlastitu pažnju i pamćenje (npr. "Imam slabo pamćenje."); 4) subskala potrebe za kontrolom misli odnosi se na vjerovanje da se određene misli trebaju kontrolirati, potisnuti (npr. "Trebao bih stalno imati kontrolu nad svojim mislima."); 5) subskala kognitivne samosvjesnosti opisuje tendenciju opažanja misli (npr. "Stalno preispitujem svoje misli."). Upitnik je preveden na hrvatski jezik te su provjerene njegove metrijske karakteristike. Provedena je analiza čestica koja je pokazala zadovoljavajuće karakteristike: sve subskale imaju zadovoljavajuće i visoke koeficijente pouzdanosti koji se kreću u rasponu od $\alpha=.74$ za subskalu kognitivne samosvjesnosti do $\alpha=.86$ za subskalu kognitivnog povjerenja.

Skalu ruminacije (Ruminative Responses Scale - RRS; Nolen-Hoeksema i Morrow, 1991) čine 22 čestice koje se odnose na značenje koje ruminacija ima za osobu, na osjećaje vezane uz depresivno raspoloženje, na simptome te na posljedice i uzroke depresivnog raspoloženja. Učestalost pojedinih simptoma ispitanici procjenju na skali od 1 (nikad) do 4 (uvijek). Ukupni se rezultat formira kao linearna kombinacija procjena na svim česticama. Viši rezultat upućuje na veći stupanj ruminacije. Neke su od čestica: "Razmišljam o tome kako sam umoran ili me nešto boli." ili "Razmišljam o tome kako se teško koncentriram." Skala je prevedena na hrvatski jezik te je temeljem unaprijed definirane originalne jednofaktorske strukture provedena analiza čestica kojom je utvrđena zadovoljavajuća pouzdanost skale $(\alpha=.96)$.

Skala pozitivnih vjerovanja o ruminaciji (Positive Beliefs about Rumination Scale-PBRS; Papageorgiou i Wells, 2001a) je jednofaktorska skala koja se sastoji od 9 čestica (npr. "Kako bih našao uzroke svoje depresije, trebam ruminirati o svojim 
problemima."). Slaganje se s pojedinim tvrdnjama procjenjuje na skali od 1 (uopće se ne slažem) do 4 (u potpunosti se slažem). Viši rezultat na skali upućuje na pozitivnija vjerovanja o ruminaciji. Za potrebe je ovog istraživanja Skala prevedena na hrvatski jezik te je provjerom njezinih metrijskih karakteristika utvrđena zadovoljavajuća pouzdanost $(\alpha=.93)$.

Skala negativnih vjerovanja o ruminaciji (Negative Beliefs about Rumination Scale - NBRS; Papageorgiou i Wells, 2001b) sastoji se od 13 čestica, a slaganje s pojedinim česticama procjenjuje se na skali od 1 (uopće se ne slažem) do 4 (u potpunosti se slažem). Ukupni se rezultat formira kao linearna kombinacija procjena na svim česticama pri čemu viši rezultat upućuje na negativnija vjerovanja o ruminaciji. Skala ima dvofaktorsku strukturu; jedan se faktor (NMRS 1) odnosi na nekontrolabilnost i štetnost ruminacije (npr. "Ne mogu kontrolirati ruminiranje o svojim problemima."), a drugi (NBRS 2) na interpersonalne i socijalne posljedice ruminacije (npr. "Ljudi će me odbaciti ako ruminiram."). Skala je prevedena na hrvatski jezik te je provedena analiza čestica pokazala zadovoljavajuće koeficijente pouzdanosti $(\alpha=.92$ i $\alpha=.84)$

Skalu usredotočene svjesnosti (Mindful Attention Awareness Scale - MAAS; Brown i Ryan, 2003) čini 15 čestica (npr. "Obavljam poslove i zadatke automatski a da nisam svjestan što radim."), a sudionici procjenjuju koliko su često usmjereni, odnosno svjesni pojedinih iskustava na skali od 1 (uvijek) do 6 (nikad). Ukupni se rezultat oblikuje kao linearna kombinacija samoprocjena na tim česticama. Visoki rezultat na skali upućuje na visoku usredotočenost. Nakon što je prevedema na hrvatski jazik, a prema unaprijed definiranoj originalnoj faktorskoj strukturi, provedena je analiza čestica, koja je pokazala zadovoljavajuću pouzdanost $(\alpha=.89)$.

Skala potiskivanja misli (White Bear Supression Inventory - WBSI; Wegner i Zanakos, 1994) se sastoji od 15 čestica (npr. "Želio bih da mogu prestati misliti o određenim stvarima.") koje opisuju načine potiskivanja misli, a slaganje s česticama procjenjuje se na skali od 1 (potpuno se ne slažem) do 5 (potpuno se slažem). Ukupni se rezultat oblikuje kao linearna kombinacija samoprocjena na svim česticama. Viši rezultat na skali upućuje na veću tendenciju potiskivanju misli. Nako prijevoda na hrvatski jezik provedena je analiza čestica pokazala dobru pouzdanost $(\alpha=.91)$.

Beckov inventar depresivnosti (Beck Depression Inventory-II - BDI-II; Beck, Steer i Brown, 1996) hrvatska je prilagođena verzija Beck Depression Inventory, koji se sastoji od 21 čestice, a svaka je čestica lista od četiri izjave poredane po težini određenog simptoma depresije. Skala ima visoku pouzdanost $(\alpha=.97)$.

U Tablici 1. prikazani se deskriptivni podaci za navedeni instrumentarij. 
Tablica 1. Deskriptivna statistika korištenog instrumentarija

\begin{tabular}{|c|c|c|c|c|}
\hline Skale & $\begin{array}{l}\text { Raspon } \\
\text { rezultata } \\
\text { (broj } \\
\text { čestica) }\end{array}$ & $\begin{array}{l}\text { Prosječni rezultat } \\
\text { (standardna } \\
\text { devijacija) }\end{array}$ & $\begin{array}{l}\text { Pouzdanost } \\
\text { (Cronbach } \\
\text { alpha) }\end{array}$ & $\begin{array}{l}\text { Prosječna } \\
\text { korelacija među } \\
\text { česticama }\end{array}$ \\
\hline \multicolumn{5}{|l|}{$\begin{array}{l}\text { Subskale Upitnika } \\
\text { metakognitivnih vjerovanja }\end{array}$} \\
\hline $\begin{array}{l}\text { 1. Pozitivna vjerovanja o } \\
\text { brizi }\end{array}$ & $\begin{array}{l}6-24 \\
(N=6)\end{array}$ & $\begin{array}{ll}M_{k}=16.31 & (3.81) \\
M_{n k=14.82} & (4.74)\end{array}$ & .77 & .37 \\
\hline $\begin{array}{l}\text { 2. Negativna vjerovanja o } \\
\text { nekontrolabilnosti i } \\
\text { opasnosti brige }\end{array}$ & $\begin{array}{c}6-24 \\
(N=6)\end{array}$ & $\begin{array}{r}M_{k}=19.80 \\
M_{n k}=13.55\end{array}$ & .84 & .48 \\
\hline 3. Kognitivno povjerenje & $\begin{array}{c}6-23 \\
(N=6)\end{array}$ & $\begin{array}{rr}M_{k}=17.32 & (3.92) \\
M_{n k}=10.52 & (3.50) \\
\end{array}$ & .86 & .52 \\
\hline 4. Potreba za kontrolom & $\begin{array}{c}6-23 \\
(N=6)\end{array}$ & $\begin{aligned} M_{k}=18.01 & (3.52) \\
M_{n k}=12.14 & (3.86)\end{aligned}$ & .77 & .36 \\
\hline $\begin{array}{l}\text { 5. Kognitivna } \\
\text { samosvjesnost }\end{array}$ & $\begin{array}{c}7-24 \\
(N=6) \\
\end{array}$ & $\begin{array}{rr}M_{k}=17.35 & (2.76) \\
M_{n k}=15.50 & (3.97) \\
\end{array}$ & .74 & .38 \\
\hline Skala ruminacije & $\begin{array}{l}22-88 \\
(N=22)\end{array}$ & $\begin{aligned} M_{k} & =61.84(11.85) \\
M_{n k} & =35.44 \quad(7.65)\end{aligned}$ & .96 & .57 \\
\hline $\begin{array}{l}\text { Skala pozitivnih vjerovanja o } \\
\text { ruminaciji }\end{array}$ & $\begin{array}{l}9-36 \\
(N=9)\end{array}$ & $\begin{array}{rr}M_{k}=26.40 & (5.70) \\
M_{n k}=17.81 & (7.25)\end{array}$ & .93 & .62 \\
\hline $\begin{array}{l}\text { Skala negativnih vjerovanja } \\
\text { o nekontrolabilnosti i } \\
\text { štetnosti ruminacije }\end{array}$ & $\begin{array}{l}9-35 \\
(N=9)\end{array}$ & $\begin{array}{rr}M_{k}=25.90 & (6.70) \\
M_{n k}=9.70 & (3.24)\end{array}$ & .92 & .59 \\
\hline $\begin{array}{l}\text { Skala negativnih vjerovanja } \\
\text { o interpersonalnim i } \\
\text { socijalnim posljedicama } \\
\text { ruminacije }\end{array}$ & $\begin{array}{l}4-16 \\
(N=4)\end{array}$ & $\begin{aligned} M_{k}=14.05 & (5.02) \\
M_{n k}=5.27 & (2.02)\end{aligned}$ & .84 & .59 \\
\hline $\begin{array}{l}\text { Skala usredotočene } \\
\text { svjesnosti }\end{array}$ & $\begin{array}{l}21-83 \\
(N=15)\end{array}$ & $\begin{aligned} M_{k} & =41.47(12.85) \\
M_{n k} & =58.42(10.85)\end{aligned}$ & .89 & .36 \\
\hline Skala potiskivanja misli & $\begin{array}{c}19-70 \\
(N=15)\end{array}$ & $\begin{array}{rr}M_{k}=57.75 & (9.59) \\
M_{n k}=47.30 & (11.78)\end{array}$ & .91 & .41 \\
\hline $\begin{array}{l}\text { Beckov inventor } \\
\text { depresivnosti }\end{array}$ & $\begin{array}{c}0-59 \\
(N=21)\end{array}$ & $\begin{array}{c}M_{k}=35.60(12.25) \\
M_{n k}=5.47 \quad(6.43)\end{array}$ & .97 & .62 \\
\hline
\end{tabular}

Legenda: $M_{k}=$ aritmetička srednina - klinička skupina; $M_{n k \text { - }}$ aritmetička sredina - ne-klinička skupina

\section{Rezultati}

\section{Povezanost ispitanih varijabli kod kliničke i ne-kliničke skupine}

Povezanost je između ispitanih varijabli provjerena korelacijskom analizom koja pokazuje da kod kliničke skupine stupanj depresivnosti ima najveću povezanost sa stupnjem ruminacije i usredotočene svjesnosti dok je kod ne-kliničke skupine najveća povezanost depresivnosti s ruminacijom te pozitivnim vjerovanjima o ruminaciji i potiskivanjem misli (Tablica 2.). 


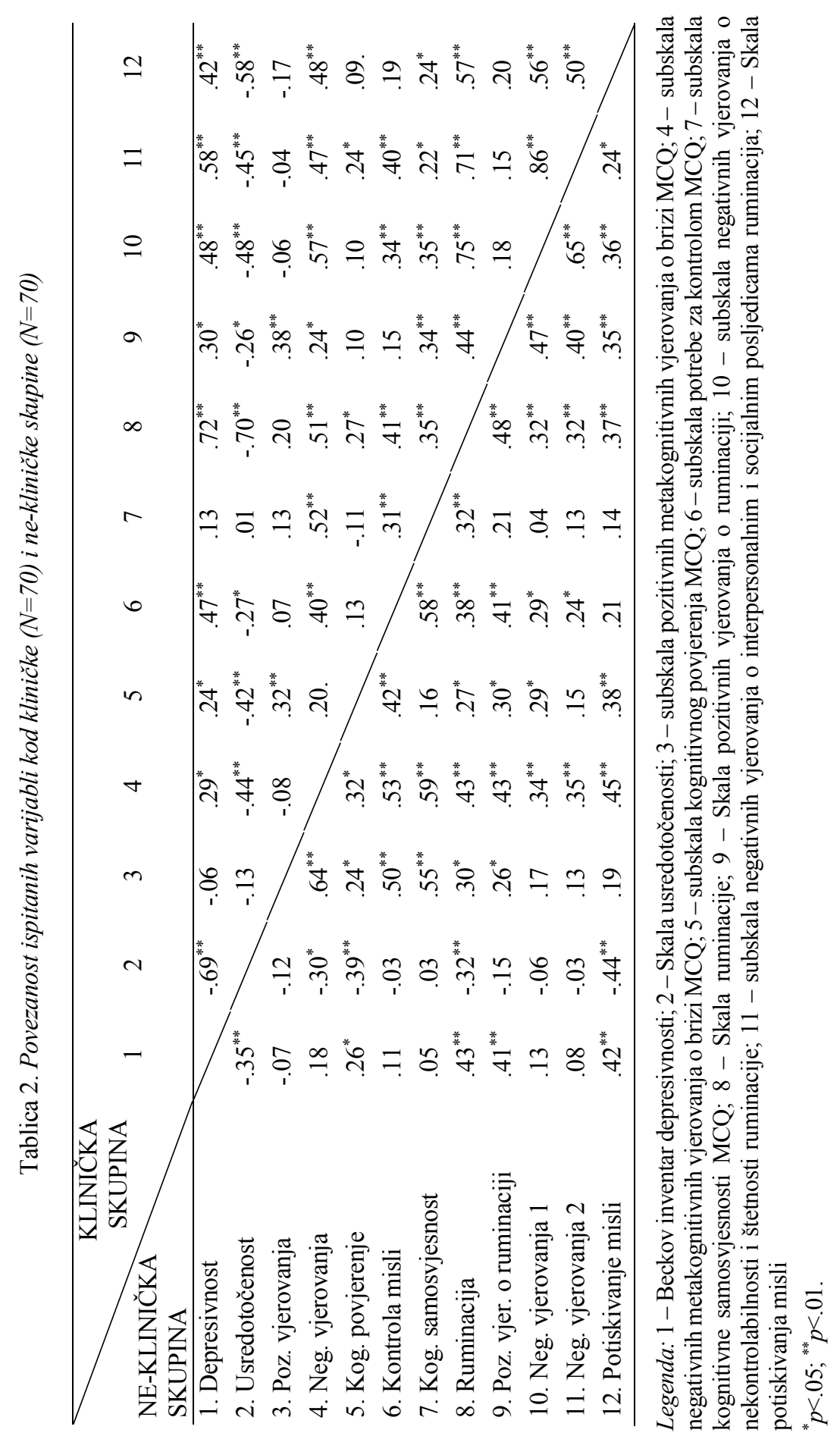


Kod obiju skupina ruminacija statistički značajno i visoko korelira sa stupnjem usredotočenosti, potiskivanja misli te pozitivnim i negativnim vjerovanja o ruminaciji. Stupanj ruminacije kod ne-depresivnih osoba ima visoku povezanost $\mathrm{s}$ rezultatima na svim subskalama Upitnika metakognitivnih vjerovanja dok je kod depresivnih osoba ta povezanost značajna kod svih subskala osim pozitivnih vjerovanja o brizi. Može se zaključiti da povezanost među ovim varijablama pokazuje sličan trend kod obiju skupina. Porast je ruminativnih misli povezan $\mathrm{s}$ porastom depresivnosti dok su pozitivnija vjerovanja o korisnosti ruminacije povezana s većim stupnjem ruminacije. Osobe koje više potiskuju misli, više i ruminiraju te imaju niži stupanj usredotočene svjesnosti bez obzira na simptome depresivnog poremećaja.

\section{Doprinos pojedinih varijabli stupnju ruminacije kod kliničke i ne-kliničke skupine}

U svrhu su provjere doprinosa pozitivnih vjerovanja o ruminaciji, usredotočene svjesnosti i potiskivanja misli stupnju ruminacije provedene odvojene analize za pojedine skupine ispitanika pod hijerarhijskim modelom koji nam je omogućio izravnu usporedbu prediktivne "snage" pojedinih varijabli. Prediktorske su varijable uvođene u sukcesivnim koracima prema unaprijed određenom redoslijedu na temelju teorijskih spoznaja i početnog pretpostavljenog odnosa. U prvom je koraku analize procijenjen doprinos pozitivnih vjerovanja o ruminaciji i stupnja ruminacije, $\mathrm{u}$ drugom je ispitan samostalni doprinos usredotočene svjesnosti povećanju objašnjene varijance kriterija, a u trećem samostalni aditivni doprinos varijable potiskivanja misli. Značajni su prediktori za obje skupine prikazani u Tablici 3.

Tablica 3. Značajni prediktori u objašnjenju stupnja ruminacije kod kliničke i ne-kliničke skupine

\begin{tabular}{lcccccc} 
& \multicolumn{2}{c}{ Klinička skupina } & \multicolumn{2}{c}{ Ne-klinička skupina } \\
\cline { 2 - 7 } Prediktori & $R\left(R^{2}\right)$ & $\Delta R^{2}$ & $\beta$ & $R\left(R^{2}\right)$ & $\Delta R^{2}$ & $\beta$ \\
\hline $\begin{array}{l}1 . \text { korak } \\
\text { Pozitivna } \\
\text { vjerovanja o }\end{array}$ & $.44(.19)$ & & & $48(.23)$ & & $.40^{*}$ \\
ruminaciji & & & $.26^{*}$ & & & \\
\hline $\begin{array}{l}\text { 2. korak } \\
\text { Usredotočena } \\
\text { svjesnost }\end{array}$ & $.75(.56)$ & $.37^{*}$ & & $.54(.29)$ & $.06^{*}$ & \\
\hline $\begin{array}{l}3 . \text { korak } \\
\text { Potiskivanje misli }\end{array}$ & $.77(.60)$ & $.03^{*}$ & & & & \\
\hline
\end{tabular}
" $p<.05$. 
Kod kliničke je skupine utvrđeno da varijable iz svakoga koraka analize značajno doprinose objašnjavanju stupnja ruminacije, pri čemu je ukupno objašnjeno $60 \%$ varijance kriterija. U posljednjem su koraku analize sve varijable zadržale statistički značajan samostalan i izravan doprinos te je utvrđeno da najznačajniji doprinos ruminaciji ima usredotočena svjesnost, a zatim pozitivna vjerovanja o ruminaciji i potiskivanje misli.

Kod ne-kliničke je skupine objašnjeno ukupno $31 \%$ varijance kriterija pri čemu jedino pozitivna vjerovanja zadržavaju prediktivnu važnost sve do posljednjeg koraka analize. Uvođenjem je potiskivanja misli, u posljednjem koraku, svoj značajan doprinos ruminaciji izgubila i usredotočena svjesnost.

\section{Doprinos pojedinih varijabli stupnju depresivnosti kod kliničke i ne-kliničke skupine}

Daljnjim je regresijskim analizama provjeren doprinos usredotočene svjesnosti, potiskivanja misli, ruminacije i negativnih metakognitivnih vjerovanja stupnju depresivnosti kod obiju skupina posebno. U prvom je koraku analize procijenjena povezanost usredotočene svjesnosti i stupnja depresivnosti, u drugom je ispitan samostalni doprinos potiskivanja misli povećanju objašnjene varijance kriterija, $\mathrm{u}$ trećem samostalni doprinos ruminacije, a u četvrtom doprinos varijabli negativnih vjerovanja o ruminaciji. Značajni su prediktori iz provedne analize prikazani $\mathrm{u}$ Tablici 4.

Tablica 4. Značajni prediktori u objašnjenju stupnja depresivnosti kod kliničke $i$ ne-kliničke skupine

\begin{tabular}{|c|c|c|c|c|c|c|}
\hline & & & & \multirow{2}{*}{\multicolumn{3}{|c|}{ Ne-klinička skupina }} \\
\hline \multirow{2}{*}{ Prediktori } & \multicolumn{3}{|c|}{ Klinička skupina } & & & \\
\hline & $R\left(R^{2}\right)$ & $\Delta R^{2}$ & $\beta$ & $R\left(R^{2}\right)$ & $\Delta R^{2}$ & $\beta$ \\
\hline 1.korak & $.69(.47)$ & & & $.35(.12)$ & & \\
\hline $\begin{array}{l}\text { Usredotočena } \\
\text { svjesnost }\end{array}$ & & & $-.40^{*}$ & & & \\
\hline $\begin{array}{l}\text { 2. korak } \\
\text { Potiskivanje misli }\end{array}$ & .69 (.47) & .00 & & $.45(.21)$ & $.08^{*}$ & $.26^{*}$ \\
\hline $\begin{array}{l}\text { 3. korak } \\
\text { Ruminacija }\end{array}$ & $.77(.59)$ & $.12^{*}$ & $.46^{*}$ & $.53(.28)$ & $.07^{*}$ & \\
\hline $\begin{array}{l}\text { 4. korak } \\
\text { Negativna vjer. } 1 \\
\text { Negativna vjer. } 2\end{array}$ & $.80(.64)$ & $.05^{*}$ & $\begin{array}{l}.39^{*} \\
.44^{*}\end{array}$ & $.53(.28)$ & .00 & $.32^{*}$ \\
\hline
\end{tabular}

Legenda: Negativna vjer. 1 - negativna vjerovanja o nekontrolabilnosti i štetnosti ruminacije; Negativna vjer. 2 - negativna vjerovanja o interpersonalnim i socijalnim posljedicama ruminacije ${ }^{*} p<.05$. 
Uvođenjem je varijable usredotočene svjesnosti u prvom koraku objašnjeno $47 \%$ varijance stupnja depresivnosti u kliničkoj skupini. Potiskivanje misli u drugom koraku nije značajno pridonijelo stupnju depresivnosti dok je doprinos ruminacije značajan i ukupnom je postotku objašnjene varijance pridonio za dodatnih $12 \%$. U posljednjem su koraku uvedene varijable negativnih vjerovanja o nekontrolabilnosti $i$ štetnosti ruminacije te interpersonalnim i socijalnim posljedicama ruminacije čime se postotak ukupno objašnjene varijance povećao na $64 \%$. Analiza je pokazala da kod depresivnih osoba stupnju depresivnosti značajno pridonose ruminacija, negativna vjerovanja o nekontrolabilnosti i štetnosti ruminacije, negativna vjerovanja o interpersonalnim i socijalnim posljedicama ruminacije te stupanj usredotočenosti, dok potiskivanje misli nema značajan doprinos.

Kod ne-kliničke skupine prediktorske varijable objašnjavaju ukupno $28 \%$ varijance depresivnosti. Sve su varijable osim negativnih vjerovanja pokazale značajan samostalni doprinos objašnjenju kriterija. Naime, u posljednjem se koraku uvođenjem negativnih metakognitivnih vjerovanja postotak objašnjene varijance nije promijenio niti su njihovi samostalni doprinosi statistički značajni. Dakle, stupnju depresivnosti kod mentalno zdravih osoba značajno doprinose ruminacija i potiskivanje misli.

\section{Razlike u ispitanim varijablama između kliničke i ne-kliničke skupine}

$\mathrm{S}$ ciljem provjere razlika između kliničke i ne-kliničke skupine u stupnju ruminacije, pozitivnim i negativnim vjerovanjima o ruminaciji, stupnju usredotočene svjesnosti, metakognitivnim vjerovanjima te stupnju potiskivanja misli provedena je diskriminacijska analiza. Temeljem dobivenih vrijednosti na pojedinim subskalama Upitnika metakognitivnih vjerovanja može se zaključiti da depresivne osobe pokazuju pozitivnija vjerovanja o brizi, negativnija vjerovanja o nekontrolabilnosti i opasnosti brige, veće kognitivno povjerenje, veću potrebu za kontrolom misli i veću kognitivnu samosvjesnost od sudionika bez smetnji mentalnog zdravlja. Depresivne osobe također imaju značajno veći stupanj ruminacije kao i pozitivnija vjerovanja o ruminaciji te imaju značajno manju razinu usredotočene svjesnosti i veću sklonost potiskivanju misli u odnosu na mentalno zdrave osobe.

Razlike su između skupina, s obzirom na odabrane varijable uzete istodobno, statistički značajne uz rizik manji od $1 \%$, čime se pokazalo opravdanim izvođenje diskriminacijske funkcije (Tablica 5.).

Tablica 5. Provjera značajnosti razlikovanja kliničke i ne-kliničke skupine na temelju diskriminacijskih varijabli

\begin{tabular}{cccccc}
\hline Eigen - vrijednost & $\begin{array}{c}\text { Koeficijent } \\
\text { kanoničke } \\
\text { korelacije }\end{array}$ & $\begin{array}{c}\text { Wilks } \\
\text { Lambda }\end{array}$ & Hi-kvadrat & $d f$ & $P$ \\
\hline 2.64 & .85 & .27 & 171.73 & 11 & $<.01$ \\
\hline
\end{tabular}


U Tablici 6. prikazani su standardizirani diskriminacijski koeficijenti koji upućuju na nezavisan doprinos diskriminacijske varijable u diskriminacijskoj funkciji. Najveći samostalni doprinos formiranju rezultata na diskriminacijskoj funkciji ima varijabla ruminacije. Sljedeće su po redu veličine nezavisnog doprinosa varijable kognitivnog povjerenja, negativnih vjerovanja o ruminaciji te negativnih vjerovanja o opasnosti brige. Dakle, po samostalnom doprinosu to su relativno najvažnije varijable u formiranju rezultata na diskriminacijskoj funkciji.

Tablica 6. Koeficijenti diskriminacijske funkcije i odnos diskriminacijskih varijabli s formiranom diskriminacijskom funkcijom na uzorku kliničke i ne-kliničke skupine

\begin{tabular}{lcc}
\hline & $\begin{array}{c}\text { Standardizirani } \\
\text { koeficijent }\end{array}$ & $\begin{array}{c}\text { Koeficijent } \\
\text { strukture }\end{array}$ \\
\hline Ruminacija & -.87 & -.82 \\
Kognitivno povjerenje & -.44 & -.57 \\
Pozitivna vjerovanja o brizi & .27 & -.11 \\
Potreba za kontrolom & -.18 & -.49 \\
Potiskivanje misli & .25 & -.30 \\
Negativna vjerovanja o brizi & -.33 & -.49 \\
Kognitivna samosvjesnost & .25 & -.17 \\
Usredotočena svjesnost & -.22 & .44 \\
Negativna vjerovanja 2 & .38 & -.51 \\
Negativna vjerovanja 1 & -.32 & -.62 \\
Pozitivna vjerovanja o ruminaciji & .02 & -.41 \\
\hline
\end{tabular}

Koeficijenti strukture pokazuju povezanost pojedine diskriminacijske varijable $\mathrm{s}$ diskriminacijskom funkcijom bez obzira na ostale varijable u funkciji. Najveću povezanost s diskriminacijskom funkcijom koja maksimalno razlikuje dvije skupine ima varijabla ruminacije. Slijede uz nešto niži koeficijent korelacije varijable negativnih vjerovanja o ruminaciji, kognitivno povjerenje, potreba za kontrolom te negativna vjerovanja o brizi.

Tablica 7. Post hoc klasifikacija sudionika na temelju diskriminacijske funkcije

\begin{tabular}{lcc}
\hline & \multicolumn{2}{c}{$\begin{array}{c}\text { Grupe formirane prema rezultatu } \\
\text { diskriminacijske funkcije }\end{array}$} \\
\hline Pripadnost skupini & Klinička & Ne-klinička \\
Klinička (70) & 66 & 4 \\
Ne-klinička (70) & 3 & 67 \\
Postotak točnih klasifikacija & $94.29 \%$ & $95.71 \%$ \\
\hline
\end{tabular}

Na osnovi post hoc analize zaključujemo da postotak točno klasificiranih sudionika na temelju diskriminacijske funkcije iznosi 95\%. Dobivena se diskriminacijska funkcija pokazala doista uspješna u klasifikaciji, te je razlikovanje 
dviju skupina sudionika (klinička i ne-klinička skupina) na ovim varijablama izrazito visoko i daleko veće od onog koje bismo očekivali po slučaju.

\section{Rasprava}

Cilj je ovog istraživanja bio utvrditi doprinos metakognitivnih vjerovanja, ruminacije, potiskivanja misli i usredotočenosti objašnjenju razine depresivnosti kod kliničke i ne-kliničke skupine te ispitati povezanost među ispitanim varijablama. Kod obju se skupina pokazalo da je ruminacija povezana s depresivnosti te s pozitivnim vjerovanjima o ruminaciji, odnosno da osobe koje vjeruju u korisnost ruminiranja češće i više ruminiraju nego osobe koje nemaju takvo vjerovanje, te da ih takav način razmišljanja vodi i do većeg stupnja depresivnosti. No, to nije slučaj kod odnosa negativnih vjerovanja o ruminaciji i stupnja depresivnosti. Naime, kod nedepresivnih osoba depresivnost nije povezana $\mathrm{s}$ negativnim vjerovanjima $\mathrm{o}$ ruminaciji, nego samo sa stupnjem ruminacije i depresivnosti. Moguće je objašnjenje da kod osoba koje nisu depresivne ili koje imaju blaže emocionalne smetnje ruminativno razmišljanje potiče učestalost negativnih misli i direktno pridonosi porastu depresivnosti i bez posredovanja negativnih metakognicija o posljedicama i štetnosti istih. Kod depresivnih osoba negativna vjerovanja o posljedicama ruminacije vode porastu depresivnosti, što je u skladu i s dosadašnjim istraživanjima koja navode da negativne posljedice ruminacije vode negativnim procjenama kontrolabilnosti i posljedicama ruminacije koje jednim dijelom posreduju u odnosu ruminacije i depresije (Papageorgiou i Wells, 2003; Roelofs i sur., 2010).

Rezultati ovog istraživanja također pokazuju da su ruminacija, depresivnost i potiskivanje misli značajno povezani kod obiju skupina. Naime, uočava se da osobe koje ruminiraju također ulažu i velik napor kako bi potisnule svoje negativne misli, no kako je potiskivanje misli često neefikasna strategija suočavanja, kod takvih osoba dolazi do porasta osjećaja depresivnosti. Povezanost je uočena i sa stupnjem usredotočene svjesnosti. Veća razina svjesnosti je kao komponenta usredotočenosti, povezana s nižom depresivnošću pri čemu svjesnost predstavlja dio kognitivnog stila koji potiče efikasno rješavanja problema kod klinički depresivnih osoba i smanjuje razinu depresivnosti. S druge strane, osobe bez poteškoća mentalnog zdravlja koje imaju veće razine usredotočene svjesnosti pokazuju i nižu sklonost ruminiranju o svojim depresivnim mislima te time i nižu razinu procjenjene depresivnosti.

Može se zaključiti da odnos ruminacije, depresivnosti, pozitivnih vjerovanja o ruminaciji, potiskivanja misli i usredotočene svjesnosti pokazuje sličan trend kod kliničke i ne-kliničke skupine. Osobe koje češce ruminiraju češće i potiskuju svoje misli te imaju niži stupanj usredotočene svjesnosti pri čemu nije od osobite važnosti imaju li ili nemaju izraženu depresivnu simptomatologiju.

Provedena hijerarhijska analiza kod kliničke skupine potvrdila je da i uz kontrolu pozitivnih vjerovanja o ruminaciji, usredotočena svjesnost značajno 
doprinosi objašnjenju individualnih razlika u stupnju ruminacije depresivnih osoba, odnosno, da i potiskivanje misli bez obzira na stupanj usredotočenosti i stupanj pozitivnih vjerovanja o ruminaciji, značajno doprinosi ruminaciji. Depresivne osobe očito rabe potiskivanje misli kao strategiju suočavanja kojom pokušavaju odvratiti svoje negativne misli kako bi postigli bolje psihičko stanje, no u konačnici se pojavnost tih misli značajno povećava. $\mathrm{S}$ druge strane, kod osoba koje nisu depresivne potiskivanje misli nije relevantno za njihov stupanj ruminacije, te je očito da kod njih ruminacija nastaje zbog pozitivnih vjerovanja u korisnost ruminacije kao strategije suočavanja i niskog stupnja usredotočene svjesnosti te stoga samo potiskivanje misli ne predstavlja značajan samostalni prediktor ruminacije.

Najveći doprinos razini depresivnosti kod depresivnih osoba ima ruminacija koja predstavlja i medijator efekta pozitivnih vjerovanja na stupanj depresivnosti, dok negativna metakognitivna vjerovanja posreduju u odnosu između ruminacije i depresivnosti. Kod ne-kliničke skupine depresivnosti najviše doprinose ruminacija i potiskivanje misli što bi se moglo objasniti time da je ruminativno razmišljanje kod blagih emocionalnih smetnji direktno povezano s negativnim mislima i sa sniženom motivacijom za reakciju dok je kod depresivnih osoba, zbog njihove pretjerane negativne usmjerenosti na sebe, povezanost ruminacije i depresivnosti posredovana upravo tim negativnim metakognitivnim vjerovanjima o štetnosti same ruminacije.

Kao i neka ranija istraživanja i ovo je istraživanje potvrdilo značajan odnos potiskivanja misli i depresije (Spinhoven i van der Does, 1999; Wenzlaff i Rude, 2002). Potiskivanje misli pokazalo se važnim faktorom povećanja pristupačnosti i učestalosti pojavljivanja negativnih misli. Naime, depresivne osobe za distrakciju češće odabiru negativnije misli nego ne-depresivne osobe jer su im one dostupnije i sličnije vlastitim depresivnim mislima.

Rezultati provedenog istraživanja potvrđuju model koji smo pretpostavili te upućuju na važnost negativnih metakognicija u odnosu između ruminacije i depresivnosti kod depresivnih osoba. S druge strane, kod ne-depresivnih osoba doprinos je usredotočene svjesnosti stupnju depresivnosti posredovan utjecajem potiskivanja misli pri čemu su se potiskivanje misli i ruminacija pokazali značajnim u predikciji depresivnosti. Očito je da kod osoba koje nemaju emocionalne smetnje ruminacija o negativnim mislima i osjećajima, kao i nastojanje da se te misli potisnu, pridonosi dostupnosti i učestalosti takvih misli što vodi porastu stupnja depresivnosti.

Jedan je od problema ovog istraživanja bio ispitati razlike između kliničke i nekliničke skupine te temeljem dobivenih rezultata možemo zaključiti da depresivne osobe značajno više ruminiraju, imaju pozitivnija vjerovanja o ruminaciji, sklonije su potiskivanju misli te imaju niži stupanj usredotočene svjesnosti u odnosu na osobe bez poteškoća metalnog zdravlja. Bez obzira na postojanje depresivnog poremećaja povezanost između ruminacije, metakognitivnih vjerovanja, depresivnosti, potiskivanja misli i usredotočene svjesnosti ipak pokazuje sličan trend. Razliku između skupina čini jedino povezanost ruminacije i depresivnosti koja je kod kliničke skupine posredovana negativnim vjerovanjima o posljedicama istih dok je 
kod ne-kliničke skupine ruminacija direktno povezana sa stupnjem depresivnosti. Ove se dvije skupine najviše razlikuju u stupnju ruminacije što je i bilo za očekivati s obzirom na brojna dosadašnja istraživanja koja upravo ovaj misaoni proces navode kao najvažniji u nastanku, održavanju ali i u tretmanu depresivnog poremećaja.

Dobivenim smo rezultatima potvrdili veliki značaj ruminacije kao misaonog procesa koji doprinosi depresivnosti, ali smo i pridonjeli stjecanju jasnijeg uvida u značajnost drugih misaonih procesa koji su važni u objašnjenju depresivnosti. S metodološkog aspekta, instrumenti koji su primijenjeni u ovom istraživanju dosada nisu bili korišteni na našem području, te njihov prijevod i prva primjena na kliničkom i ne-kliničkom uzorku ispitanika predstavljaju doprinos u smislu prikupljanja relevantnih informacija o instrumentariju koji se može koristiti i u budućim istraživanjima. Jedno se od ograničenja ovog istraživanja odnosi na veličinu uzorka jer bi s većim uzorkom bilo opravdanije provoditi dodatne statističke analize kojima bi se provjerili uzročno-posljedični odnosi među ispitanim varijablama. Preporuke za daljnja istraživanja svakako bi uključivala dodatnu validaciju korištenog istrumentarija te njihovu primjenu na većem uzorku ispitanika kliničke i ne-kliničke skupine.

Praktične kliničke implikacije mogu se odnositi na dodatne smjernice u psihoterapijskom pristupu koji bi u tretmanu depresivnog poremećaja trebao uključivati i tretman ruminacije i trening usredotočene svjesnosti. Neki od novijih terapijskih modela koji uključuju kognitivno bihevioralni tretman ruminacije (Watkins i sur., 2007) upućuju na važnost kognitivne terapije usredotočene svjesnosti (Teasdale i sur., 2000; Wells, 2009) i pokazuju njihovu značajnu korist u liječenju depresivnog poremećaja.

Naime, tretmani usmjereni na ruminaciju temelje se na premještanju pozornosti s depresivnog, neefikasnog načina razmišljanja na efikasnije načine upotrebom funkcionalne analize, tehnika imaginacije i bihevioralnih eksperimenata. Rezultat je ovakog pristupa značajna remisija depresivnih simptoma (Watkins i sur., 2007). Također, suvremenija terapija depresivnog poremećaja, metakognitivna terapija, ističe važnost rada na misaonim procesima pri čemu se ovladava načinima prekidanja ruminacije i jačanja metakognitivnih vještina kojima se klijent distancira od negativnih misli. Rezultati ovog istraživanja dodatno potvrđuju važnost metakognicija u nastanku i objašnjenju depresije te imaju svoje značajne implikacije na unapređenje psihoterapijskog rada s depresivnim osobama. 


\section{Literatura}

Beck, A.T., Steer, R.A. i Brown, G.K. (1996). BDI-II manual. San Antonio: The Psychological Corporation.

Beevers, C.G., Wenzlaff, R.M., Hayes, A.M. i Scott, W.D. (1999). Depression and the ironic effects of thought suppression: Therapeutic strategies for improving mental control. Clinical Psychology: Science and Practise, 6(2), 133-148.

Bishop, S.R., Lau, M., Shapiro, S., Carlson, 1., Anderson, N.D., Carmody, J., Segal, Z.V., Abbey, S., Speca, M., Velting, D. i Devins, G. (2004). Mindfulness: A proposed operational definition. Clinical Psychology: Science and Practice, 11(3), 230-241.

Borders, A., Earleywine, M. i Jajodia, A. (2010). Could mindfulness decrease anger, hostility and agression by decreasing rumination? Aggressive Behavior, 36(1), 28-44.

Brotman, M.A. i Derubies, R.J. (2004). A comparison and appraisal of theories of rumination. U: C. Papageorgiou i A. Wells (Ur.), Depressive rumination: Nature, theory and treatment (str. 177-186). England: John Wiley.

Brown, K.W. i Ryan, R.M. (2003). The benefits of being present: Mindfulness and its role in psychological well-being. Journal of Personality and Social Psychology, 84(4), 822-848.

Chambers, R., Lo, B.C.Y. i Allen, N.B. (2008). The impact of intensive mindfulness training on attentional control, cognitive style and affect. Cognitive Therapy and Research, 32(3), 303-322.

Coffey, K.A. i Hartman, M. (2008). Mechanisms of action in the inverse relationship between mindfulness and psychological distress. Complemental Health Practice Review, 13(2), 79-91.

Lybomirsky, S., Tucker, K.L., Caldwell, N.D. i Berg, K. (1999). Why ruminators are poor problem solvers: Clues from the phenomenology of dysphoric rumination. Journal of Personality and Social Psychology, 77(5), 1041-1060.

Martin, L.L. i Teser, A. (1989). Toward a motivational and structural theory of ruminative thought. U: R.S. Wyer, JR. (Ur.), Ruminative thoughts (str. 1-47). Hillsdale, NJ: Lawrence Erlbaum.

Moulds, M.L., Yap, C.S.L., Kerr, E., Williams, A.D. i Kandris, E. (2010). Metacognitive beliefs increase vunerability to rumination. Applied Cognitive Psychology, 24(3), 351364.

Nolen-Hoeksema, S. (1991). Responses to depression and their effects on the duration of depressive episodes. Journal of Abnormal Psychology, 100(4), 569-582.

Nolen-Hoeksema, S. i Morow, J. (1991). A prospective study of depression and posttraumatic stress symptoms after a natural disaster. Journal of Personality and Social Psychology, 61(1), 115-121.

Papageorgiou, C. i Wells, A. (2001a). Positive beliefs about depressive rumination: Development and preliminary validation of a self-report scale. Behavior Therapy, 32, 13-26.

Papageorgiou, C. i Wells, A. (2001b). Metacognitive beliefs about rumination in recurrent major depression. Cognitive and Behavioral Practice, 8, 160-164. 
Papageorgiou, C. i Wells, A. (2003). An empirical Test of a clinical metacognitive model of rumination and depression. Cognitive Therapy and Research, 27(3), 261-273.

Purdon, C. (1999). Thought suppression and psychopathology. Behaviour Research and Therapy, 37(11), 1029-1054.

Reynolds, M. i Wells, A. (1999). The Thought Control Questionnaire-psychometric properties in a clinical sample, and relationship with PTSD and depression. Psychological Medicine, 29(5), 1089-1099.

Roelofs, J., Huibers, M., Peeters, F., Arntz, A. i van Os, J. (2010). Positive and negative beliefs about depressive rumination: A psychometric evaluation of two self-report scales and a test of a Clinical metacognitive model of rumination and depression. Cognitive Therapy and Research, 34(1), 196-205.

Shapiro, S.L., Carlson, L.E., Astion, J.A. i Freedman, B. (2006). Mechanisms of mindfulness. Journal of Clinical Psychology, 62(3), 373-386.

Smith, J.M. i Alloy, L.B. (2009). A roadmap to rumination: A review of the definition, assessment, and conceptualization of this multifaceted construct. Clinical Psychology Review, 29(2), 116-128.

Spinhoven P. i van der Does, W. (1999). Thought suppression, dissociation and psychopathology. Personality and Individual Differences, 27(5), 877-886.

Teasdale, J.D., Segal, Z.V., Williams, J.M.G., Ridgeway, V.A., Soulsby, J.M. i Lau, M.A. (2000). Prevention of relapse/reccurence in major depression by mindfulness-based cognitive therapy. Journal of Consulting and Clinical Psychology, 68, 615-623.

Watkins, E.R., Scott, J., Wingrove, J., Rimes, K.A., Bathurst, N. i Steiner, H. (2007). Rumination-focused cognitive behaviour therapy for residual depression: A case series. Behaviour Research and Therapy, 45, 2144-2154.

Wegner, D.M. (1994). Ironic processes of mental control. Psychological Review, 101(1), 3452.

Wegner, D.M. i Zanakos, S. (1994). Chronic thought suppression. Journal of Personality, 62(4), 616-640.

Wells, A. (2009). Metacognitive therapy for anxiety and depression. New York: The Guilford Press.

Wells, A. i Cartwright-Hatton, S. (2004). A short form of the metacognitions questionnaire: Properties of the MCQ-30. Behaviour Research and Therapy, 42(4), 385-396.

Wells, A. i Matthews, G. (1996). Modelling cognition in emotional disorder: The S-REF Model. Behaviour Research and Therapy, 34(11-12), 881-888.

Wenzlaff, R.M. i Rude, S.S. (2002). Cognitive vunerability to depression: The role of thought supression and attitude certainty. Cognition and Emotion, 16(4), 533-548.

Williams, J.M.G. (2008). Mindfulness, depression and modes of mind. Cognitive Therapy and Research, 32, 721-733.

World Health Organization - WHO (2012). Depression. A global public health concern. Preuzeto s http:/www. who.int/mental_health 


\title{
Contribution of Rumination, Mindfulness, Thought Suppression and Metacognitive Beliefs in Depression
}

\begin{abstract}
Previous studies on the role of cognitive processes in explaining the origin and development of depression indicated the importance of gaining a clearer view of their relations. This research tried to test the contribution of metacognitive beliefs, rumination, thought suppression and mindfulness, explaining the levels of depression and examining their relationship in clinical and non-clinical group.

The clinical group $(N=70)$ included individuals suffering from a depressive disorder and non-clinical $(N=70)$ consisted of people without mental health problems. The results showed that depressed people ruminate more, have more positive beliefs about rumination, lower levels of mindfulness, often suppress thoughts, and have more negative beliefs about the dangers and consequences of rumination than mentally healthy people. In depressed individuals rumination is mediated by negative beliefs about the consequences of rumination, while in mentally healthy people rumination is directly related to the level of depression. Results may represent additional guidance in the psychotherapeutic approach and the treatment of depressive disorders should include treatment of rumination and mindfulness training.
\end{abstract}

Keywords: depression, rumination, metacognitive beliefs, mindfulness, thought suppression

\section{Contribución de la rumiación, concentración, supresión de pensamientos y creencias metacognitivas a la explicación de la depresión}

\section{Resumen}

Los estudios existentes sobre el papel de los procesos cognitivos para explicar la aparición y el desarrollo de la depresión han indicado la importancia de obtener perspicacia más clara en su interconexión. Por eso, el objetivo de esta investigación fue verificar la contribución de las creencias metacognitivas, rumiación, supresión de pensamientos y concentración a la explicación del grado de depresión, tanto como examinar su interconexión dentro de los grupos clínico y no clínico. El grupo clínico $(\mathrm{n}=70)$ constaba de personas que sufren del trastorno depresivo y el grupo no clínico $(n=70)$ de personas sin dificultades mentales. Los resultados obtenidos han demostrado que las personas depresivas, en comparación con las personas mentalmente sanas, rumían más, tienen ideas más positivas sobre la rumiación y mente menos centrada, suprimen los pensamientos con más frecuencia y tienen ideas más negativas sobre los peligros y las consecuencias de la rumiación. Cuando se trata de las personas depresivas, la contribución de la rumiación tiene como mediador las ideas negativas sobre las consecuencias de la rumiación, mientras que la rumiación está directamente relacionada con el grado de la depresión cuando se trata de las personas mentalmente sanas. Los resultados ofrecen directrices adicionales para el enfoque psicoterapéutico que en el tratamiento del trastorno depresivo debería incluir el tratamiento de rumiación y el ejercicio de mente centrada.

Palabras claves: depresión, rumiación, creencias metacognitivas, mente centrada, supresión de pensamientos

Primljeno: 18.04.2016. 